SNOWY EGRET AT

EROOKED LAKE,

SASKATCHEWAN

DON WEIDL, Box 435, Broadview, baskatchewan, SOG OKO.

Over the past five years people in he Crooked Lake area have reported grets to me along the Qu'Appelle River near Sunset Beach resort. lowever, I have never followed up hese reports until this year.

On 5 May 1978, Milton Criddle of Broadview told me that he had seen n egret on the Qu'Appelle. At 0900 n 7 May, George Anderson and I vere travelling along Highway No. 47 when we spotted an egret near he Qu'Appelle River approximately $.0 \mathrm{~km}$ east of Sunset Beach on rooked Lake. We walked down to he river to get a better look and to y to photograph the bird. We ushed it several times, getting good iews through $8 \times 40$ binoculars and everal pictures with a $35 \mathrm{~mm}$ camera nd telephoto lens. It was not until he bird flew that I was satisfied that pis was a Snowy Egret.

The white body, black bill and legs, ellow feet and closed " $S$ " of the eck when flying were the identifying eatures. ${ }^{3}$ We then canoed down the Du'Appelle to try getting closer to he egret and take more pictures. By lowly drifting with the current we ere able to get within $50 \mathrm{~m}$ of the ird getting excellent views.

There have been a few other ightings of the Snowy Egret in askatchewan, but to my knowledge - photographs were obtained. oyce Gunn saw a Snowy Egret at pirit Lake, 23-29 May 1956.1 Mr. E. ox and Mr. A. Swanston saw Snowy grets east of Craven on 9 July 956. 5 Wayne Weber saw a Snowy gret on 19 June 1970 at the Cypress
Lake dam, south of Maple Creek, Saskatchewan. 5 On 15 May 1977 and 3-4 June 1978, J. B. Gollop and others studied single adults near Saskatoon. ${ }^{2} 4$

IANAKA, W. 1956. The Snowy Egret. Blue Jay 14:89-90.

2O'NEIL, D. P. 1978. Saskatoon birds, May 30-July 26, 1978. Saskatoon Field Notes 7(2):1-10.

${ }^{3}$ ROBBINS, C. S., B. BRUUN and H. S. ZIM. 1966. Birds of North America. Golden Press, New York.

4SERR, E. M. 1977. Northern Great Plains Region, American Birds 31:1013-1016.

5WEBER, W. C. 1971. Sight record of a Snowy Egret at Cypress Lake, Saskatchewan. Blue Jay 29:134-135.

\section{FURTHER NOTES ON THE ARRIVAL OF THE HOUSE SPARROW}

C. STUART HOUSTON, 863 University Drive, Saskatoon, Saskatchewan, S7N $0 J 8$.

My article on the spread of the House Sparrow ${ }^{2}$ overlooked two important early reports, from Carberry. Manitoba and Carnduff. Saskatchewan.

Ernest Thompson Seton ${ }^{3}$ reported that the House Sparrow "first appeared at Carberry in 1892. but was not found in numbers until 1894." This antedates Macoun's 1894 Winnipeg report by two years. By early 1909. Seton said this new arrival was "found in all the settled portions of Manitoba, and at every farmhouse and in all the towns of the North-west as far as Athabaska Landing. Alberta." 